\title{
IMUNISASI SAAT PANDEMI COVID-19 DI KAMPUNG SUDIMAMPIR DESA CIMANGGIS KEC.BOJONGGEDE KAB.BOGOR TAHUN 2020
}

\author{
Sindi Serliyanti ${ }^{1}$, Andi Asnifatima ${ }^{2}$ \\ 1,2Program Studi Kesehatan Masyarakat, Fakultas Ilmu Kesehatan, Universitas Ibn Khaldun Bogor \\ Email : ${ }^{1}$ yserli391@gmail.com, ${ }^{2}$ asni@uika-bogor.ac.id
}

\begin{abstract}
Abstrak
Pandemi covid-19 yang saat ini terjadi di beberapa negara salah satunya adalah Indonesia, membuat masyarakat Indonesia harus terbiasa dengan semua perubahan mulai dari kehidupan sehari-hari, pekerjaan, peribadahan bahkan sampai dengan pelayanan kesehatan misalnya kegiatan posyandu. Kondisi ini juga dihadapi oleh warga Rt 02 Rw 03 Desa Cimanggis Kecamatan Bojonggede Kabupaten Bogor. Oleh karena itu diperlukan program yang dapat meningkatan pengetahuan masyarakat mengenai imunisasi saat pandemi covid19 program ini bernama Edukasi online. Tujuan umum dari kegiatan pengabdian masyarakat ini adalah untuk meningkatan pengatahuan masyarakat mengenai pandemi covid-19. Sedangkan tujuan khusus yang ingin dicapai dalam kegiatan pengabdian ini adalah ibu tetap membawa anaknya untuk imunisasi, ibu mendapatkan informasi mengenai pentingnya imunisasi bagi kesehatan anak, dan ibu mengetahui cara membawa anak untuk imunisasi saat pandemi covid 19 dan tetap terjaga dari penularan virus covid 19. Metode yang digunakan dalam program ini adalah melalui daring atau online dengan memanfaatkan jajaring komunikasi whatsapp grup. Metode evaluasi dalam kegiatan ini dengan memberikan survey serta melakukan assesmen manual. Hasil yang dicapai menunjukan peningkatan pengetahuan masyarakat mengenai pandemi covid-19 dan pentingnya tetap melakukan imunisasi saat pandemi covid-19. Sehingga dapat disimpulkan kegiatan ini dapat menjadi salah satu cara untuk meningkatkan pengetahuan masyarakat.
\end{abstract}

Kata Kunci : Pandemi Covid-19, Imunisasi, Pelayanan Kesehatan.

\section{PENDAHULUAN}

\section{Analisis Situasi}

Secara geografis, Kabupaten Bogor terletak diantara 6¹8"0" - 647"10" Lintang Selatan dan $106^{\circ} 23^{\prime \prime 4} " 5^{\prime \prime}-107^{\circ} 13^{\prime \prime} 30^{\prime \prime}$ Bujur Timur, yang berdekatan dengan Ibu kota Negara yaitu sebagai pusat pemerintahan, jasa dan perdagangan dengan aktifitas pembangunan yang cukup tinggi. Kabupaten Bogor merupakan salah satu kabupaten di Provinsi Jawa Barat dengan Ibu kota kabupaten yang terletak di Kecamatan Cibinong. Secara administrasi, Kabupaten Bogor mempunyai luas 298.838, 30 ha yang terdiri dari 40 kecamatan yang di dalamnya meliputi 417 desa dan 17 kelurahan (434 desa/kelurahan), yang tercakup dalam 3.882 RW dan 15.561 RT. Wilayah Bojonggede memiliki 9 desa dengan luas wilayah 2.824,69 atau $0,95 \%$.

Hasil Identifikasi awal yang diambil pada 40 warga sebagai sampel dari RT 02 dan diperoleh gambaran perilaku dan pengetahuan masyarakat saat pandemi covid-19 secara umum. Jika berdasarkan potensi tertular dari luar rumah data menunjukan warga tidak 
menggunakan angkutan umum seperti angkot, bus, kereta api, ojek online, taxi namun masih banyak juga indikator yang membutuhkan intervensi lebih lanjut agar masyarakat mengetahui dan paham bagaimana pentingnya tetap mengikuti protokol pencegahan covid-19 diantaranya masih tingginya jumlah warga yang tidak menggunakan masker saat berpergian keluar rumah yaitu sekitar 82,5\%, sekitar 74,4\% mengatakan bahwa masih menyentuh barang yang sebelumnya juga disentuh oleh orang lain. Sementara berdasarkan potensi tertular dari dalam rumah data menunjukan 67,5\% masyarakat tidak menyediakan hand sanitizer didepan pintu rumahnya masing- masing.

\section{Permasalahan yang Dihadapi}

Semakin tingginya jumlah kasus infeksi penyakit Covid-19 yang terjadi di Indonesia sampai dengan tanggal 12 September 2020 sudah terdapat 214.746 kasus konfirmasi, 53.649 dalam perawatan, 152.458 kasus sembuh dan 8.650 kasus meninggal. Membuat masyarakat Indonesia harus terbiasa dengan semua perubahan mulai dari kehidupan sehari-hari, pekerjaan, peribadahan bahkan sampai dengan pelayanan kesehatan misalnya kegitaan posyandu.

Kondisi ini juga dihadapi oleh warga Rt 02 Rw 03 Desa Cimanggis Kecamatan Bojonggede Kabupaten Bogor. Pelaksaaan imunisasi pada bayi dan balita di posyandu saat pandemi covid-19 dengan tidak saat pandemi tentu sangat berbeda dan harus diketahui oleh kader posyandu maupun orang tua dari bayi atau balita yang menjadi peserta aktif posyandu, pelaksanaan imunisasi yang sesuai dengan protokol kesehatan tentunya dapat mencegah kader, petugas kesehatan, ibu dan anak terinfeksi covid-19, serta anak dapat merasakan manfaat imunisasi sehingga kita dapat bersama-sama mencegah terjadinya wabah baru yaitu wabah penyakit yang bisa dicegah dengan imunisasi.

\section{Solusi Yang Ditawarkan}

Masalah yang dihadapi warga Rt 02 Rw 03 yaitu pengetahuan mengenai kewajiban untuk tetap melakukan imunisasi ditengah pandemi covid-19. Dengan demikian solusi yang ditawarkan adalah melakukan Edukasi Secara Online dengan harapan agar menambah wawasan kepada masyarakat Rt 02 Rw 03. Hal ini merupakan salah satu upaya untuk memberikan informasi sekaligus memberi pemahaman kepada masyarakat mengenai pentingnya tetap melakukan imunisasi pada bayi dan balita saat pandemi covid-19.

Imunisasi adalah suatu upaya untuk meningkatkan kekebalan seseorang secara aktif terhadap suatu penyakit, sehingga apabila suatu saat terjadi indikasi pada salah satu penyakit tersebut maka tidak akan mengalami kesakitan yang begitu parah atau hanya mengalami sakit ringan.

Edukasi atau disebut juga dengan pendidikan merupakan segala upaya yang direncanakan untuk mempengaruhi orang lain baik individu, kelompok, atau masyarakat sehingga mereka melakukan apa yang diharapkan oleh pelaku pendidikan (Notoadmojo, 2003) Edukasi online ini dilakukan melalui grup whatsapp yang beranggotakan ibu yang memiliki bayi dan balita sebanyak 18 orang. 


\section{Kelebihan :}

1. Tidak mengumpulkan masa sehingga dapat mencegah terjadinya penularan covid-19

2. Dilakukan secara online sehingga masyarakat dapat melihat informasi yang dikirimkan kapan saja dan bisa berkali-kali dilihat

3. Masyarakat yang menerima informasi dapat mengirimkan lagi informasi tersebut ke beberapa teman

sehingga informasi yang diberikan semakin meluas

Kelemahan :

1. Tidak diketahui apakah masyarakat sudah melihat dan membaca informasi yang diberikan

2. Tidak diketahui apakah masyrakat memahami atau tidak informasi yang diberikan

\section{DESKRIPSI LOKASI KEGIATAN}

\section{Keadaan Geografis}

Secara administrasi luas wilayah desa cimanggis adalah 520 Ha dengan titik koordinat 106.77985 BT/-6.506745 LS. Desa Cimanggis berbatasan dengan wilayah sebelah utara desa Sukmajaya/Tojong, sebelah selatan kelurahan kayu manis/mekar wangi, sebelah timur.

desa kedung waringin/waringin jaya, dan sebalah barat desa kemang/parakan jaya. Sementara secara Topografi bentang lahan daratan di desa cimanggis sebagian besar digunakan untuk ladang yaitu sebesar $174 \mathrm{Ha}$.

\section{Kondisi Demografis}

Jumlah penduduk desa cimanggis tercatat sebanyak 17.968 orang dengan rincian sebagai berikut :

Tabel 1. Jumlah Penduduk

\begin{tabular}{|l|c|}
\hline Jumlah laki-laki & 9.252 orang \\
\hline $\begin{array}{l}\text { Jumlah } \\
\text { perempua }\end{array}$ & 8.716 orang \\
\hline Jumlah Total & $\mathbf{1 7 . 9 6 8 ~ o r a n g}$ \\
\hline $\begin{array}{l}\text { Jumlah } \\
\text { kepala }\end{array}$ & $4.693 \mathrm{kk}$ \\
\hline $\begin{array}{l}\text { Kepadata } \\
\text { Penduduk }\end{array}$ & 0 Per km \\
\hline \multicolumn{2}{|l|}{ Sumber : Profil Desa Cimanggis tahun 2014 }
\end{tabular}

Tabel 2. Jumlah penduduk menurut mata pencaharian

\begin{tabular}{|l|c|c|c|}
\hline Jenis Pekerjaan & Laki-laki & Perempuan & $\begin{array}{c}\text { Jumlah } \\
\text { Orang }\end{array}$ \\
\hline Petani & 13 & 0 & 13 \\
\hline Buruh tani & 2 & 1 & 3 \\
\hline Pegawai negeri sipil & 219 & 94 & 313 \\
\hline Pengrajin & 8 & 14 & 22 \\
\hline
\end{tabular}




\begin{tabular}{|c|c|c|c|}
\hline $\begin{array}{l}\text { Pedagang barang } \\
\text { klotong }\end{array}$ & 46 & 2 & 48 \\
\hline Peternak & 12 & 4 & 16 \\
\hline Montir & 7 & 0 & 7 \\
\hline Perawat swasta & 0 & 13 & 13 \\
\hline Bidan swasta & 0 & 10 & 10 \\
\hline TNI & 26 & 0 & 26 \\
\hline POLRI & 22 & 0 & 22 \\
\hline $\begin{array}{l}\text { Pengusaha kecil, } \\
\text { menengah dan besar }\end{array}$ & 1 & 0 & 1 \\
\hline Guru swasta & 41 & 78 & 119 \\
\hline Dosen swasta & 4 & 2 & 6 \\
\hline Pedagang keliling & 7 & 5 & 12 \\
\hline $\begin{array}{l}\text { Pembantu Rumah } \\
\text { Tangga }\end{array}$ & 0 & 17 & 17 \\
\hline Dukun Tradisional & 0 & 5 & 5 \\
\hline $\begin{array}{l}\text { Karyawan perusahaan } \\
\text { swasta }\end{array}$ & 2.334 & 642 & 2.976 \\
\hline $\begin{array}{l}\text { Karyawan Perusahaan } \\
\text { Pemerintah }\end{array}$ & 20 & 1 & 21 \\
\hline Wiraswasta & 1.495 & 62 & 1.557 \\
\hline $\begin{array}{l}\text { Konsulasi Manajemen } \\
\text { dan Teknis }\end{array}$ & 0 & 1 & 1 \\
\hline Belum bekerja & 1.725 & 1.606 & 3.331 \\
\hline Pelajar & 2.279 & 1.998 & 4.277 \\
\hline Ibu Rumah Tangga & 6 & 4.191 & 4.197 \\
\hline Purnawir awan/Pen & 82 & 12 & 94 \\
\hline Perangkat Desa & 5 & 0 & 5 \\
\hline Buruh Harian Lepas & 933 & 3 & 936 \\
\hline Jumlah Total (orang) & 11.621 & 9.404 & 21.024 \\
\hline
\end{tabular}

Sumber : Profil Desa Cimanggis tahun 2014 
Tabel 3. Jumlah Tingkat Pendidikan Masyarakat

\begin{tabular}{|l|c|c|c|}
\hline Tingkat Pendidikan & Laki- laki & Perempuan & $\begin{array}{c}\text { Jumlah } \\
\text { (orang) }\end{array}$ \\
\hline Tamat SD/sederajat & 2.011 & 2.464 & 4.475 \\
\hline Tamat SMP/sederajat & 1.597 & 1.572 & 3.169 \\
\hline Tamat SMA/sederajat & 3.148 & 2.500 & 5.648 \\
\hline Tamat D- 2/sederajat & 24 & 23 & 47 \\
\hline Tamat D- 3/sederajat & 136 & 180 & 316 \\
\hline Tamat S- 1/sederajat & 473 & 309 & 782 \\
\hline Tamat S- 2/sederajat & 18 & 4 & 22 \\
\hline Tamat S- 3/sederajat & 1 & 0 & 2 \\
\hline Jumlah Total (orang) & 7.408 & 7.052 & 14.460 \\
\hline
\end{tabular}

Sumber : Profil Desa Cimanggis tahun 2014

\section{Ketersediaan Fasilitas Umum}

Pada bidang kesehatan tersedia 1 unit puskesmas, 2 unit poliklinik atau balai pengobatan, 13 unit posyandu, 1 unit balat pengobatan masyarakat yayasan atau swasta, 2 unit rumah bersalin, dan 2 unit balai kesehatan ibu dan anak. Sementara pada fasilitas pendidikan tersedia Gedung SMA/sederajat milik sendiri sebanyak 4 unit, Gedung SMP/sederajat milik sendiri sebanyak 3 unit, Gedung SD/sederajat sebanyak 5 unit, Gedung TK milik sendiri sebanyak 5 unit, Gedung Lembaga pendidikan agama milik sendiri sebanyak 2 unit, dan Gedung Perpustakaan desa/kelurahan milik sendiri sebanyak 1 unit.

Pada fasilitas Transportasi terdapat jalan desa/kelurahan berupa aspal dengan kondisi baik sepanjang 5,5 Km, jalan desa/kelurahan berupa tanah dengan kondisi baik sepanjang 2 $\mathrm{km}$, jalan desa/kelurahan berupa sirtu (pasir dan batu) dengan keadaan baik sepanjang $7 \mathrm{~km}$, jalan desa/kelurahan berupa konblok/beton dengan keadaan baik sebanyak $2 \mathrm{~km}$, jalan antar desa/kelurahan/kecamatan berupa aspal dengan keadaan baik sepanjang $4 \mathrm{~km}$, jalan antar desa/kelurahan/kecamatanberupa tanah dengan kondisi baik sepanjang $2 \mathrm{~km}$, jalan kabupaten berupa aspal dengan kondisi baik sepanjang $4 \mathrm{~km}$, jembatan beton dengan kondisi baik sebanyak 3 unit, dan pangkalan ojek dengan kondisi baik sebanyak 3 unit.

Sarana peribadatan berupa masjid sebanyak 13 unit,dan mushola sebanyak 25 unit. Terdapat sumur pompa sebanyak 1.630 unit dan sumur gali sebanyak 1.612 unit. Selain itu, terdapat 10 unit sumur resapan air ruamh tangga, MCK umum sebanyak 1 unit, jamban keluarga (KK) sebanyak 1.610 unit. Untuk fasilitas olahraga terdapat 3 unit lapangan bulu tangkis, 2 unit lapangan sepak bola, 1 unit lapangan tenis, 2 unit lapangan voli dan 2 unit meja pingpong. 
METODE PELAKSANA

Tahapan Pelaksanaan

Tahapan Pelaksanaan untuk kegiatan ini sebagaimana terlihat pada bagan sebagai berikut:

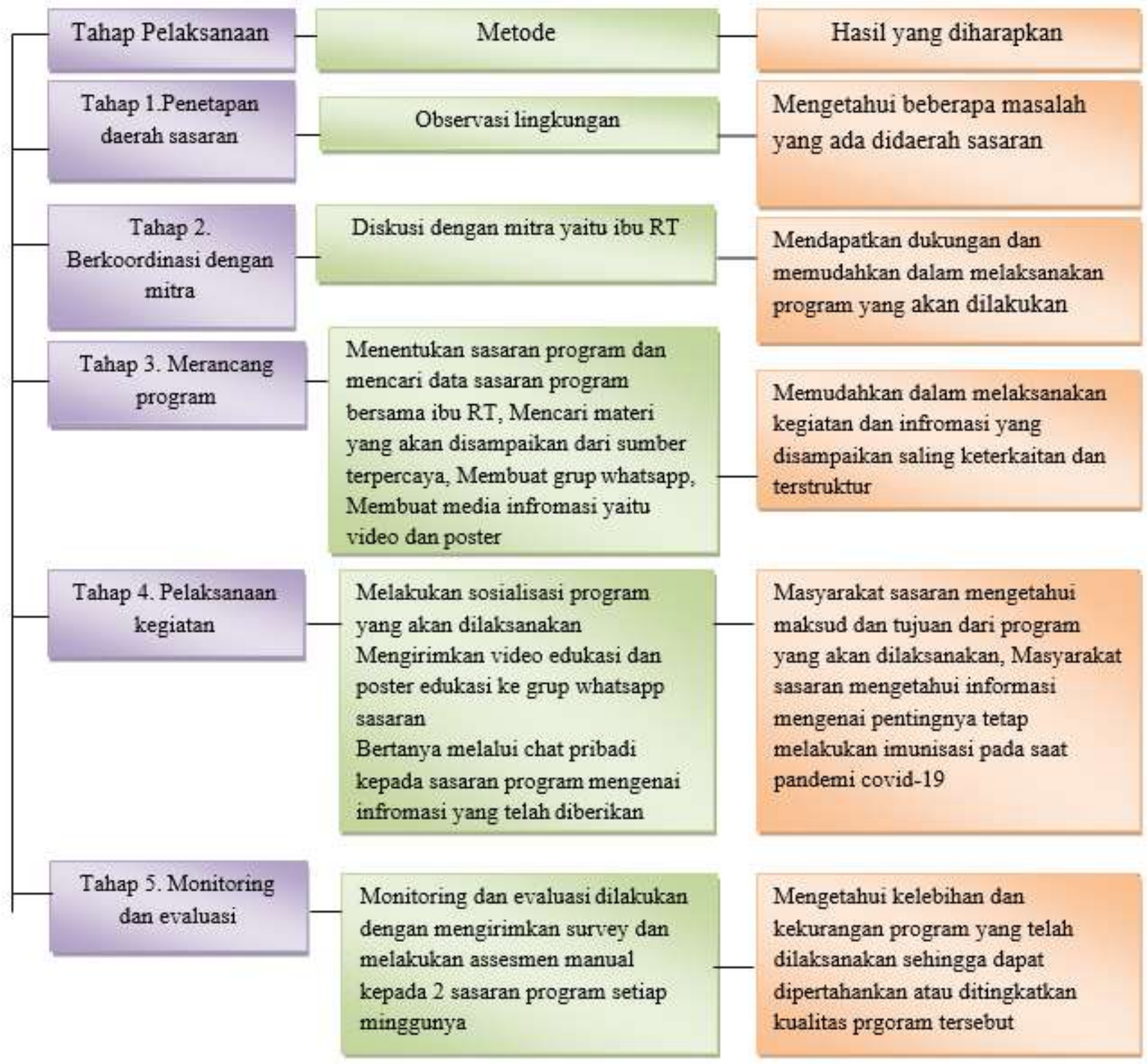

Bagan 1. Alur Pelaksanaan Program 
Jadwal Kegiatan

Tabel 4. Jadwal Kegiatan

\begin{tabular}{|c|c|c|c|c|c|c|}
\hline \multirow[t]{2}{*}{ No } & \multirow[t]{2}{*}{ Kegiatan } & \multicolumn{5}{|c|}{ Minggu } \\
\hline & & $\mathrm{I}$ & II & III & IV & $\mathrm{V}$ \\
\hline 1. & $\begin{array}{l}\text { Penetapan Daerah } \\
\text { Sasaran }\end{array}$ & & & & & \\
\hline 2. & $\begin{array}{l}\text { Berkoordinasi dengan } \\
\text { Mitra }\end{array}$ & & & & & \\
\hline 3. & Merancang Program & & & & & \\
\hline 4. & Pelaksanaan Program & & & & & \\
\hline 5. & Monitoring dan evaluasi & & & & & \\
\hline
\end{tabular}

\section{Metode Pendekatan}

Metode yang digunakan daam program ini adalah dengan memanfaatkan jejaring komunikasi whatsapp grup serta mendatangi satu persatu rumah sasaran program untuk mensosialisasikan dan meminta kesediaan sasaran dalam mengikuti kegiatan yang akan dilaksanakan.

Sasaran utama pada program ini adalah ibu dengan bayi dan balita, ibu sangat berpengaruh terhadap terlaksananya imunisasi pada anaknya sehingga ibu harus diberikan edukasi mengenai imunisasi dan dirasa sangat tepat untuk menjadi sasaran program ini.

\section{Partisipasi Masyarakat Dalam Pelaksanaan Program}

Partisipasi masyarakat yang dilakukan dalam kegiatan ini adalah sebagai berikut:

1. Melibatkan tokoh masyarakat yaitu ibu RT yang merupakah tokoh yang sangat didengar oleh warganya sehingga diharapkan dapat menjadi contoh dan mendukung terlaksananya kegiatan posyandu dengan baik, selain itu ibu RT dengan sangat bersemangat ikut serta untuk mencari data dari sasaran program dengan cara mendatangi rumah sasaran program satu-persatu.

2. Lokasi pelaksanaan program ini dilakukan di grup whatsapp yang didalamnya terdapat warga sasaran program.

3. Masyarakat sasaran program berpartisipasi dalam menilai kelancaran dan kebermanfaatan program yang dilakukan dengan cara mengisi form assesmen yang telah disediakan oleh panitia pelaksana program KKNT Covid-19 Daring.

\section{Langkah Evaluasi}

Metode evaluasi yang dilakukan adalah dengan memberikan google form yang berisi survey diberikan kepada 40 warga Rt 02 Rw 03 sebagai sampel, Survey ini dilakukan dengan cara mengirimkan link survey melalui whatsapp dan masyarakat yang telah mengisi akan mengirimkan bukti berupa screenshot. Serta melakukan assesmen manual kepada 2 sasaran program yang dilakukan dalam satu minggu sekali melalui whatsapp chat. 


\section{HASIL DAN PEMBAHASAN}

\section{Pelaksanaan Program}

Pelaksanaan kegiatan Edukasi Online mengenai imunisasi saat pandemi covid-19 dilaksanakan pada tanggal 23 Agustus 2020 dan 3 September 2020 yang berlangsung di grup whatsapp sasaran program dengan jumlah peserta 18 orang terdiri dari ibu dengan bayi dan balita yang aktif mengikuti kegiatan posyandu jaya mekar di Rt 02 Rw 03 Desa Cimanggis Kecamatan Bojonggede Kabupaten Bogor.

Pada tanggal 23 Agustus edukasi yang disampaikan adalah materi mengenai pelaksanaan imunisasi saat pandemi dilanjutkan atau ditunda, tips membawa anak imunisasi saat pandemi covid-19 serta hal apa yang perlu diperhatikan sebelum membawa anak imunisasi ke posyandu saat pandemi covid-19.

Sementara pada tanggal 3 September 2020 edukasi yang disampaikan adalah materi mengenai tugas dan peran orang tua sebelum dan saat membawa anak imunisasi ke posyandu saat pandemi covid-19.

Media yang digunakan dalam edukasi ini adalah aplikai canva untuk membuat poster, aplikasi kinemaster untuk membuat video dan whatsapp grup untuk menyampaikan materi edukasi.

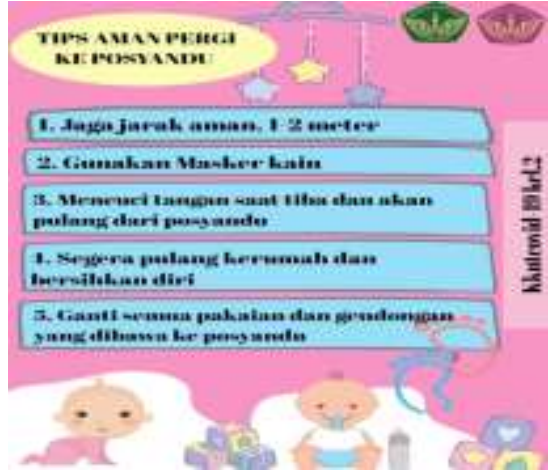

Poster edukasi

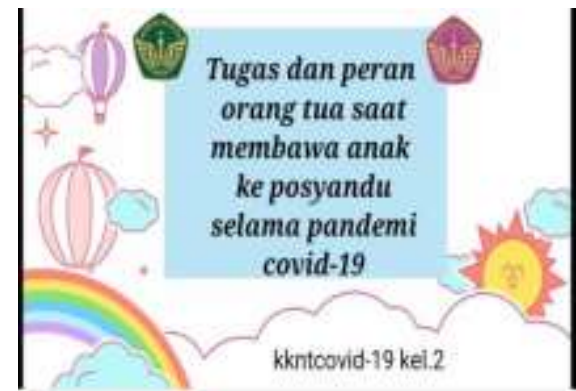

Video edukasi

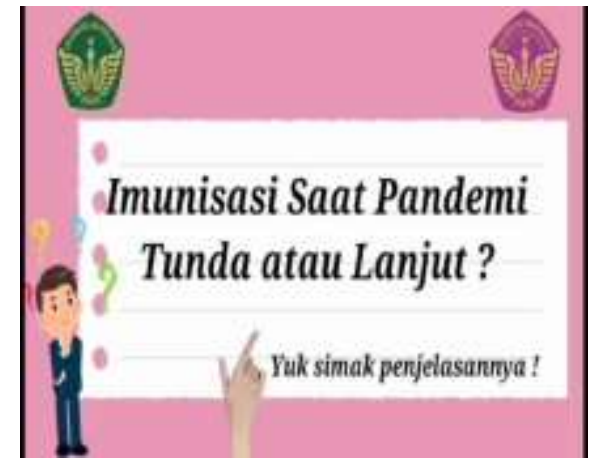

Video edukasi

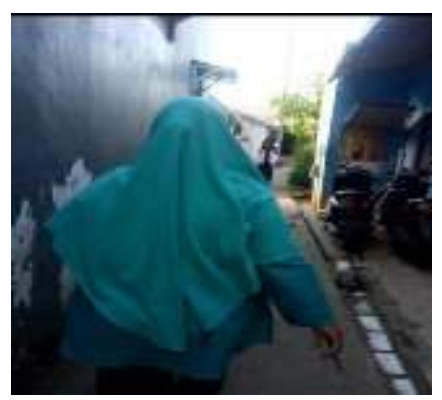

Mendata sasaran program bersama ibu RT 


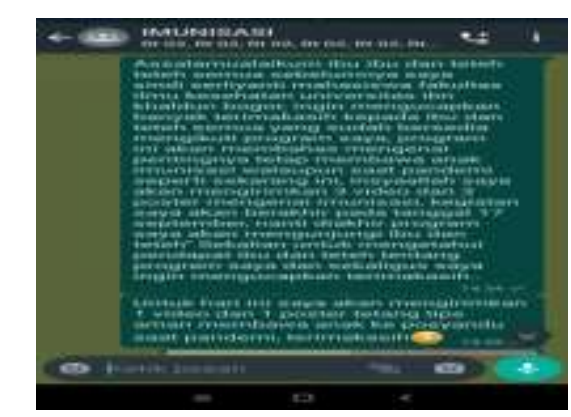

Pembuatan grup dan sosialisasi program

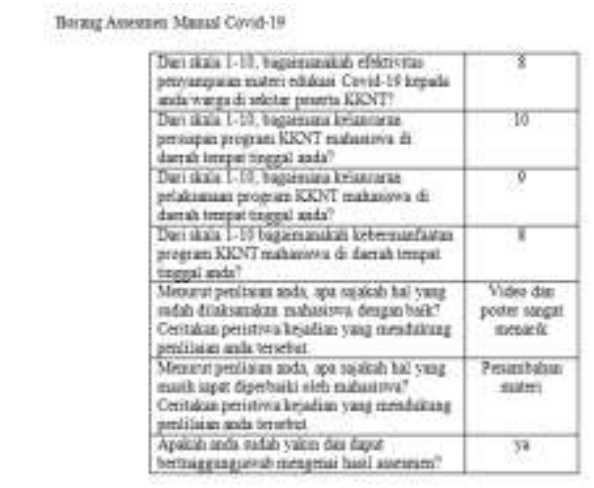

Monitoring dan evaluasi dengan

Borang Assesmen manual

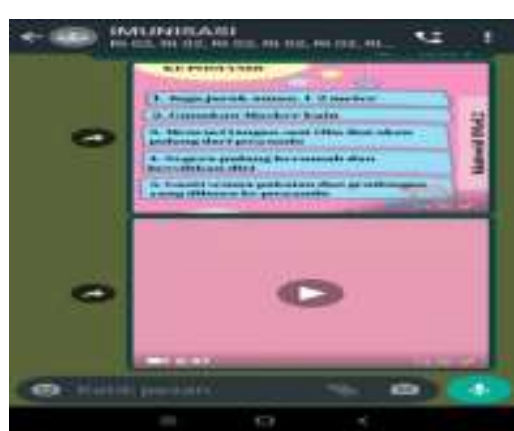

Edukasi Online

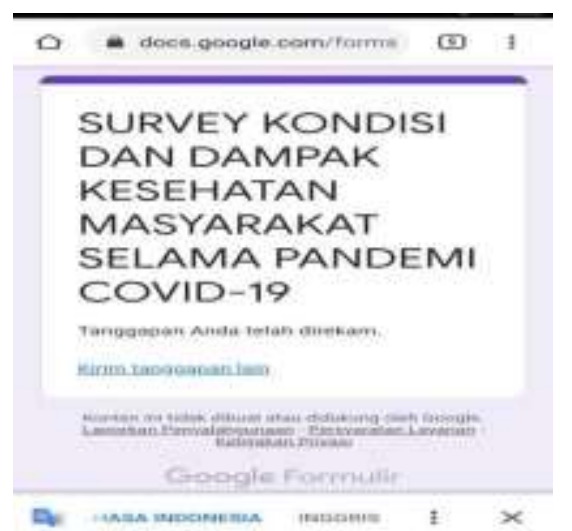

Monitoring dan evalusai dengan survey

\section{Gambar 1. Dokumentasi kegiatan}

\section{Capaian Program}

Pengukuran keberhasilan program ini adalah dengan menggunakan survey dan assesmen yang diisi oleh sasaran program.

1. Pengetahuan mengenai pentingnya tetap melakukan imunisasi pada anak saat pandemi covid-19

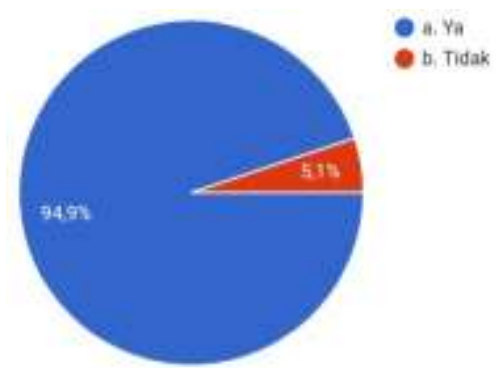

\section{Bagan 2. Pengetahuan mengenai Imunisasi}

Berdasarkan gambar diatas diketahui bahwa 94,9\% masyarakat mengetahui bawah anak tetap harus mendapatkan imunisasi walau saat pandemi covid-19 
2. Pengetahuan mengenai keadaan anak sebelum dibawa imunisasi

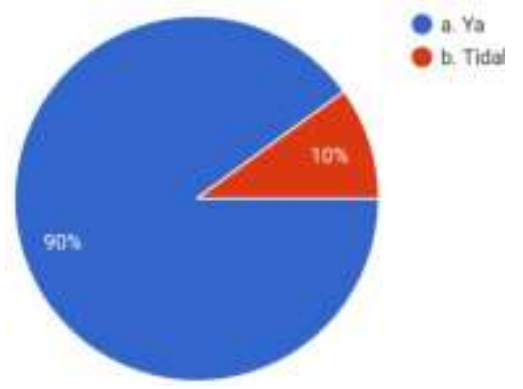

\section{Bagan 3. Pengetahuan keadaan anak sebelum imunisasi}

Berdasarkan gambar diatas diketahui bahwa 90\% masyarakat mengetahui bahwa anak harus dalam keadaan sehat sebelum diberikan imunisasi

3. Pengetahuan mengenai pentingnya imunisasi bagi kesehatan anak

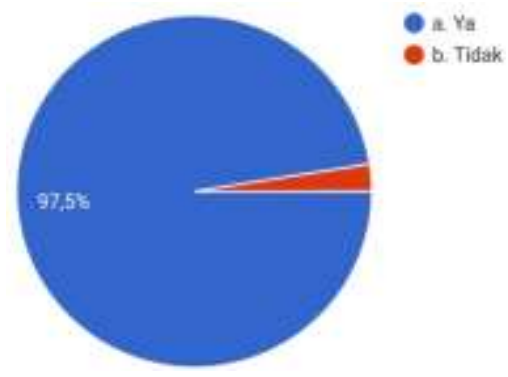

\section{Bagan 4. Pengetahuan pentingnya imunisasi}

Berdasarkan gambar diatas diketahui bahwa 97,5\% masyarakat mengenai bahwa imunisasi penting bagi kesehatan anak

4. Pengetahuan mengenai keharusan menggunakan masker bagi ibu atau orang tua yang akan mengantar anak imunisasi

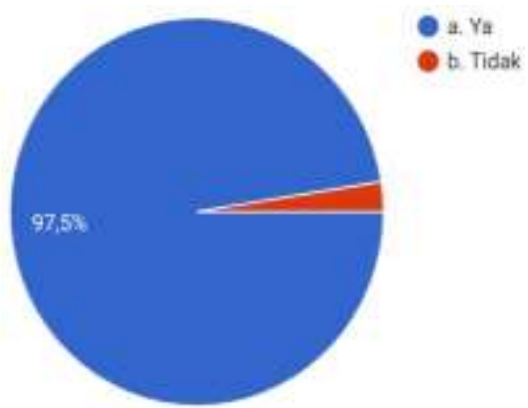

\section{Bagan 5. Pengetahuan mengenai masker}

Berdasarkan gambar diatas diketahui bahwa 97,5\% masyarakat mengetahui ibu atau orang tua yang anak mengantar anak imunisasi harus menggunakan masker

\section{Dampak Bagi Masyarakat}

Kegiatan edukasi online ini membawa dampak positif bagi masyarakat kearah yang lebih baik mulai dari pengetahuan, sikap dan perilaku. Dengan dukungan Rt dan Kader posyandu setempat akan sangat memungkinkan pemberian imunisasi kepada anak di posyandu akan terlaksana dengan baik sesuai dengan protokol kesehatan yang telah ditetapkan oleh kementerian kesehatan. 


\section{PENUTUP \\ Kesimpulan}

Kegiatan edukasi online meningkatkan pengetahuan masyarakat mengenai pentingnya tetap melakukan imunisasi saat pandemi covid-19, sehingga masyarakat khususnya ibu dengan bayi dan balita akan tetap membawa anaknya imunisasi tindakan tersebut dapat mencegah terjadinya wabah baru yaitu penyakit yang bisa dicegah dengan imunisasi.

\section{Rekomendasi}

Disarankan kepada kader posyandu agar tetap rajin memberi semangat dan nasihat kepada ibu atau orang tua yang mempunyai bayi dan balita untuk tetap konsisten membawa anak meraka melakukan imunisasi agar anak dapat terhindar dari berbagai macam penyakit.

\section{DAFTAR PUSTAKA}

Asnifatima A. Pola Kecenderungan Spasial Kejadian Malaria (Studi Kasus; di Kabupaten Kepulauan Selayar Tahun 2011 - 2013). Hearty Jurnal Kesehatan Masyarakat. 2017;5(1):1-12. http://ejournal.uikabogor.ac.id/index.php/Hearty/article/view/1051/865.

Asnifatima, A., Prakoso, I., and Fatimah, A. (2017). Faktor Risiko Keluhan Computer Vision Syndrome (CVS) Pada Operator Warung Internet Di Kecamatan Bojong Gede, Kabupaten Bogor Tahun 2017. Hearty Jurnal Kesehatan Masyarakat, 5(2), pp.1-7.

Asnifatima, A., Irfan, A. M., \& Putri, K. A. (2018). Pemberdayaan Masyarakat Melalui

Pengelolaan Sampah Rumah Tangga Di Desa Cimanggu Satu. Abdi Dosen : Jurnal Pengabdian Pada Masyarakat, 2(3). https://doi.org/10.32832/abdidos.v2i3.181

Asnifatima A, Parinduri SK, Aligori A. (2020). Risiko dan Karakterisitik Penderita Toksoplasmosis berdasarkan Demografi, Keberadaan Hewan Peliharaan, Hygiene dan Sanitasi. Heart, Jurnal Kesehatan Masyarakat,8(X), 41-49.

A Asnifatima, R Listyandini. (2020). HUBUNGAN PENGGUNAAN LEM DENGAN KONDISI FISIOLOGI PEKERJA HOME INDUSTRY DI RW04 KELURAHAN PAMOYANAN KOTA BOGOR TAHUN 2019. PROMOTOR 3 (1), 7-17

A Asnifatima. (2020). Hubungan Infertilitas dengan Toksoplasmosis pada Wanita Sudah Menikah. PROSIDING LPPM UIKA BOGOR

A Asnifatima, AD Martin, S Kalbu. (2020). PENGOLAHAN SAMPAH MANDIRI DENGAN INSENERASI SEDERHANA MINIM ASAP (INSEMA) DI KELURAHAN BOJONGKERTA, KEC. BOGOR SELATAN, KOTA BOGOR TAHUN 2019. Abdi Dosen: Jurnal Pengabdian Pada Masyarakat 4 (1), 1-12

Buku Ajar Imunisasi Oleh Pusat Pendidikan Dan Pelatihan Tenaga Kesehatan, ISBN 978-602235-809-1, 2014.

D Melinda, A Fathimah, A Asnifatima. (2021). ANALISIS RISISKO KESELAMATAN DAN KESEHATAN KERJA DI AREA UTILITY PT KALBE MILKO INDONESIA KECAMATAN CARINGIN KABUPATEN BOGOR TAHUN 2018. PROMOTOR 3 (6), 569-576

Dr. drh. Didik Budijanto, M.Kes (Kepala Pusat Data dan Informasi), dkk. Data Dan Informasi Profil Kesehatan Indonesia, 2018.

FD Firdayanti, A Asnifatima. (2021). PEMBERDAYAAN MASYARAKAT DALAM MEWUJUDKAN 
PROGRAM AGENT PERUBAHAN PEDULI COVID-19 (AADC-19) DI KAMPUNG NYENCLE. PROMOTOR 4 (5), 499-510

FW Ardianty, A Fathimah, A Asnifatima. (2021). HUBUNGAN ANTARA PAJANAN KEBISINGAN DENGAN GANGGUAN NON-AUDIOTORY PADA PETUGAS KEAMANAN DALAM (PKD) PT KERETA API INDONESIA (KAI) DI STASIUN BOGOR TAHUN 2020. PROMOTOR 4 (2), 114-121

Frequently Asked Questions(FAQ) COVID- 19 Kementerian Kesehatan RI, per 4 Maret 2020. Hartanti, HF, Asnifatima, A \& Fatimah, A. Faktor Risiko yang Berhubungan Dengan Keluhan Carpal Tunnel Syndrome Pada Pekerja Operator Komputer Bagian Redaksi di Harian Metropolitan Bogor Tahun 2018, Jurnal Mahasiswa Kesehatan Masyarakat. 2018

Meilani, F., Asnifatima, A., \& Fathimah, A. (2018). Faktor-faktor Risiko Yang Mempengaruhi Keluhan MUSCULOSKELETAL DISORDER (MSDs) Pada pekerja Operator Sewing DI PT DASAN PAN FASIFIC INDONESIA Tahun 2018. Promotor Jurnal Mahasiswa Kesehatan Masyarakat, 1(1), 1-6.

NF Ainiyyah, A Fathimah, A Asnifatima. (2021). HUBUNGAN ANTARA KEBISINGAN TERHADAP STRES KERJA PADA PEKERJA DI BAGIAN MIXING PT. ELANGPERDANA TYRE INDUSTRY TAHUN 2020. PROMOTOR 4 (4), 338-348

NR Rizqi, A Asnifatima, R Listyandini. (2021). GAMBARAN PAPARAN RISIKO CACINGAN PADA PETUGAS PENGANGKUT SAMPAH DI KECAMATAN BOJONGGEDE KABUPATEN BOGOR TAHUN 2020. PROMOTOR 4 (4), 349-358

NE Yuliana, A Asnifatima, A Fathimah. (2021). FAKTOR-FAKTOR YANG BERHUBUNGAN DENGAN KELUHAN SUBJEKTIF DERMATITIS KONTAK PADA PEKERJA PABRIK TAHU DI KECAMATAN CITEUREUP KABUPATEN BOGOR TAHUN 2020. PROMOTOR 4 (3), 253261

Pratama S., Asnifatima A., Ginanjar R., 2019 , Faktor-Faktor Yang Berhubungan Terhadap Postur Kerja Dengan Keluhan Nyeri Punggung Bawah Pada Pengemudi Bus Pusaka Di Terminal Baranangsiang Kota Bogor Tahun 2018, Promotor Jurnal Mahasiswa Kesehatan Masyarakat Vol.2, No.4

Pusat Data Dan Informasi Kementerian Kesehatan Republik Indonesia, Situasi dan Analisis Imunisasi, 2014.

Rencana Program Investasi Jangka Menangah (RPIJM) Bidang Cipta Karya Kabupaten Bogor 2015-2019

Raya, M. R., Asnifatimah, A. and Ginanjar,R. 2018.Faktor-Faktor yang Mempengaruhi Keluhan GangguanPendengaran Pada Supir Bus POPusaka Di Terminal Baranangsiang Kota Bogor Tahun 2018.Jurnal Promotor Vol 2 No 2.

R Ginanjar, A Asnifatima. (2021). ANALISIS KEBUTUHAN SISTEM TANGGAP DARUTAT DI SEKOLAH AT TAUFIQ KOTA BOGOR TAHUN 2019. PROMOTOR 3 (6), 614-623

SK Parinduri, A Asnifatima, MAA Saci, A Nasution. (2021). Peluang dan Tantangan Promosi Kesehatan Kader Kesehatan Remaja Kota Bogor. Jurnal Ilmu Kesehatan Masyarakat 10 (01), 46-54

SK Parinduri, A Asnifatima, D Ferdian. (2020). Analysis of Health Promotion Methods for Adolescent Health Cadres in Bogor City: A Case Study. Jurnal Ners dan Kebidanan Indonesia 8 (4), 16-17 